\title{
Measurement of radioactive impact of the gas well accident on environment of Sylhet division in Bangladesh
}

\author{
Shyamal Ranjan Chakraborty ${ }^{1}$, Khokan Kanti Saha ${ }^{1}$, Md. Kowsar Alam ${ }^{1, *}$, \\ Abul Khaer Mohammed Rezaur Rahman ${ }^{1}$, Masud Kamal ${ }^{2}$, \\ Mantazul Islam Chowdhury ${ }^{2}$ \\ ${ }^{1}$ Department of Physics, University of Chittagong, Chittagong - 4331, Bangladesh \\ ${ }^{2}$ Radioactivity Testing and Monitoring Laboratory, Bangladesh Atomic Energy Commission, \\ Chittagong Medical College Hospital Campus, Chittagong - 4232, Bangladesh \\ *E-mail address: kowsar.alam@yahoo.com
}

\begin{abstract}
The main goal of this study is to carry out the public exposure contribution from radioactive materials occurring due to the accident of natural gas exploration well of Sylhet division in Bangladesh. This study has been performed by using a gamma spectrometry of Genie 2000 software embedded PC-based High Purity Germanium (HPGe) detector system. The measured activity concentrations of naturally occurring radionuclides ${ }^{232} \mathrm{Th},{ }^{226} \mathrm{Ra}$, and ${ }^{40} \mathrm{~K}$ have been in the public safety limit on the environment of the study areas. The specific activity of detected anthropogenic radionuclide ${ }^{137} \mathrm{Cs}$ has been found to be very little with a mean value of $1.65 \pm 0.61$ and $1.13 \pm 0.57$ $\mathrm{Bq} \cdot \mathrm{kg}^{-1}$ in the Magurchhera and Haripur gas field area respectively.
\end{abstract}

Keywords: Natural gas well accident; Environmental radioactivity; Public exposure etc.

\section{INTRODUCTION}

Technological activities in mining and mineral processing lead to large volumes of wastes-containing naturally occurring radioactive materials (NORMS), which are dumped into the environment over prolonged periods of time. In addition, the wastes are in most cases in close proximity to densely populated areas as well as agricultural lands that spread over several kilometers. Natural radionuclide's, especially from the uranium-thorium series, may leach with time and reach dams, lakes and streams that are accessible to the public or agricultural lands. Surface water such as lakes and rivers or underground water may also be contaminated by direct discharge of large volumes of processed water that may contain radioactive materials. Farming practices can transfer contaminants through various pathways to the terrestrial environment and then to crops, vegetables and livestock. As a result, Human beings are exposed to background radiation from radioactive contaminants of natural and man-made sources. Natural background radiation, which is equivalent to $2.4 \mathrm{mSv}$ per person, accounts for $\sim 80 \%$ of the total radiation dose a person, receives annually [1]. Soil radionuclide activity concentration is one of the main determinants of the natural background 
radiation. Volcanic geographic structures as well as rocks that are rich in phosphate, granite and salt contain natural radionuclides like ${ }^{238} \mathrm{U},{ }^{232} \mathrm{Th}$ and ${ }^{40} \mathrm{~K}$. When rocks are disintegrated through natural processes, radionuclides are carried to the soil by rain and flows [2]. In addition to the natural sources, soil radioactivity is also affected by men. Caesium-137 is a fission by-product, has a half-life of $30.2 \mathrm{y}$ with gamma radiations of $0.661 \mathrm{MeV}$ [3]. Radioisotopes that are present in soil significantly affect terrestrial gamma radiation levels.

The effective gamma radiation levels are generally in the range of $18-93 \mathrm{nGy}^{\circ} \mathrm{h}^{-1}$ with a mean of $59 \mathrm{nGy} \cdot \mathrm{h}^{-1}$ [4]. Bangladesh has some natural resources; among them, natural gas contributes the largest amount. There are 26 gas fields in this country and the most of them are in Sylhet division. Three accidents have been occurred in the natural gas fields of Sylhet in the last days and amongst them, two natural gas exploration areas, Haripur and Magurchhera, have been chosen for measuring the radioactive impact on environment. The accident of these two natural gas well had been occurred in 1955 and in 1997 respectively. In Magurchhera, the exploration of this resource had been done after the necessary survey including the geophysical condition of the area. The Occidental Company of the USA had been started drilling of the gas well to elevate the natural gas in 1997. Unfortunately, the gas exploration well caught fire blew out from 840 meter depth at the time of drilling. The flame from the blazing gas rose as high as 500 feet. The sudden rise in the gas well seriously destroyed the drilling rigs and the machinery and the ${ }^{137} \mathrm{Cs}$ crystal, used in the drilling machine scattered into the environment. Sands and small pieces of stones were coming with the fire from the gas well. This might change the radiological condition of the locality. As a result, this study has been aimed for determining the environmental delayed impact of gamma radiation surrounding the gas exploration well areas and the following studies have been carried out:

(1) Determination of the radioactive concentration of natural radionuclide's ${ }^{226} \mathrm{Ra},{ }^{232} \mathrm{Th}$ and ${ }^{40} \mathrm{~K}$ in soil of Magurchhara and Haripur gas exploration well area.

(2) Determination of the radioactive concentration of artificial radionuclide ${ }^{137} \mathrm{Cs}$.

(3) Determination of the external and internal doses, radium equivalent activity and representative level index of the study area.

\section{MATERIALS AND METHODS}

\section{1. Study area and sampling}

Sylhet division is one of the charming hilly areas of Bangladesh where having various types of natural resources. Among various natural resources natural gas is the important one economically. Three gas field accidents, Haripur, Magurchhera and Tengratila (Chhatak) have been occurred in the last days. Out of which two areas have been taken into consideration of this study. The study area Magurchhera gas field is situated at Kamalgang thana and Haripur gas field is situated at Goainghat thana in Sylhet division are shown in Fig. $1 \mathrm{~A}$ and $1 \mathrm{~B}$ respectively. A total number of 35 samples have been collected from these two study areas among which 28 are from Magurchhera and 8 are from Haripur gas field area. All of the samples have been collected using a rotating cylindrical plastic corer with an amount about to $1 \mathrm{~kg}$. 


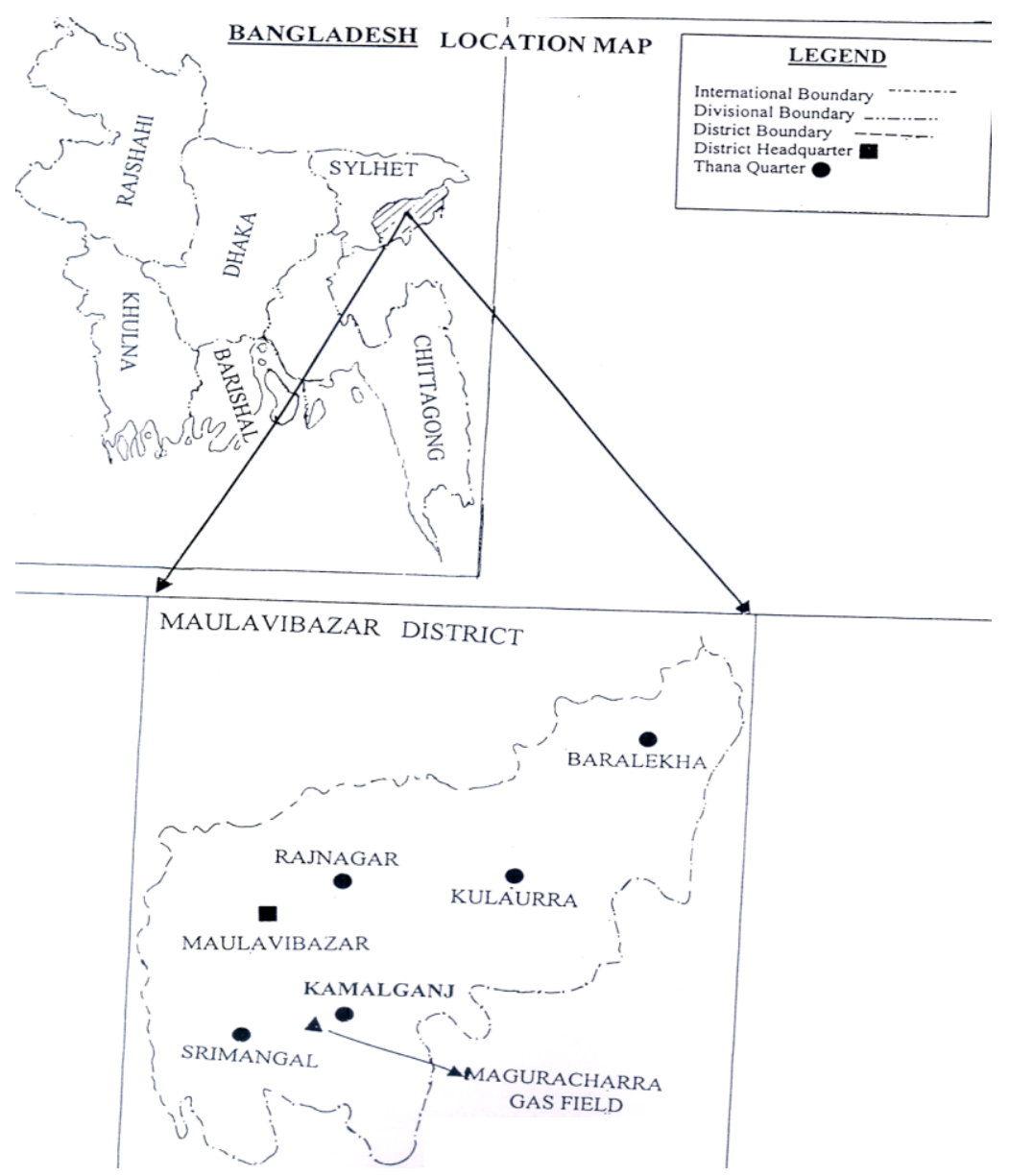

Fig. 1A. Magurchhara gas field area in Sylhet division.

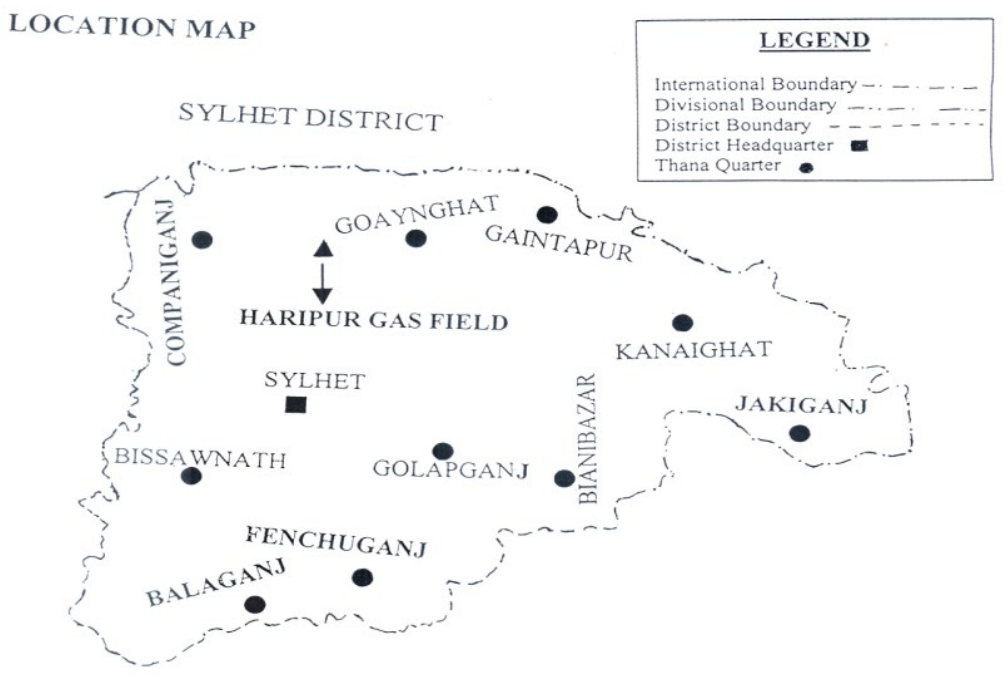

Fig. 1B. Haripur gas field area in Sylhet division. 


\subsection{Gamma spectrometry and analytical procedures}

The preparation technique which has been used for the pre-treatment of soil samples [5] in this study is given in Fig. 2. The present research work has been performed by using a ptype coaxial lead shielded intrinsic HPGe detector of $132 \mathrm{~cm}^{3}$ volume with relative efficiency of $35 \%$ and resolution (FWHM) of $1.83 \mathrm{keV}$ for the $1332 \mathrm{keV} \gamma$-ray energy of ${ }^{60} \mathrm{Co}$. For analyzing the gamma spectrum, firstly the full-energy peak efficiency curve has been plotted by measuring the reference samples IAEA/RGU-1 (U ore), IAEA/RGTh-1 (Th ore) and IAEA/RGK-1 (K sulphate) from which the counting efficiencies of the gamma-ray peaks have been measured [6,7]. The geometry of the counting samples has been the same as that of the standard samples and the counting time for all the samples has been 20,000 seconds. All the spectrum acquisition and analysis have been performed by the computer based Canberra software of Genie 2000. For calculating the net counting of the samples, the background count due to naturally occurring radionuclide's in the environment around the detector has been subtracted from each sample counts. Corrections have also been made for selfabsorption of the gamma-radiation by the samples [8,9]. The results expressed with the confidence limit or standard deviation of $\pm 1 \sigma$.

In the present study, the following formulae have been used for the calculation of the activity concentrations of the samples and the corresponding radiological impact on the environment.

(a). The counting efficiency of the detector has been calculated by using the formula [10]

$$
\text { Efficiency }(\%)=\frac{C P S \times 100}{\text { Activity } \times \text { Intensity }} \quad \text { or, } \varepsilon_{f}(\%)=\frac{C P S \times 100}{A_{C} \times I_{\gamma}}
$$

where, CPS $=$ Net count per second (i.e. CPS from standard source - CPS for background)

Activity, $A_{C}=$ Standard source activity for respective energy

Intensity, $I_{\gamma}=$ Intensities of gamma energies.

(b). Specific activities of the radionuclide's presented in the soil samples have been calculated by using the formula [11]

$$
\text { Activity }=\frac{C P S \times 100 \times 1000}{\varepsilon_{f}(\%) \times I_{\gamma} \times w_{s}(\mathrm{gm})} \quad \text { in } \mathrm{Bq} \cdot \mathrm{kg}^{-1}
$$

where, $\mathrm{w}_{\mathrm{s}}$ are the mass of the samples.

(c). The outdoor absorbed dose rates in air at $1 \mathrm{~m}$ above the ground surface (in $\mathrm{nGy} \cdot \mathrm{h}^{-1}$ ) have been calculated by using the following formula (conversion factors) $[7,12]$

$\mathrm{D}_{\text {outdoor }}=\left(0.427 \mathrm{C}_{\mathrm{Ra}}+0.66 \mathrm{C}_{\mathrm{Th}}+0.0432 \mathrm{C}_{\mathrm{K}}\right)$

where $\mathrm{C}_{\mathrm{Ra}}, \mathrm{C}_{\mathrm{Th}}$ and $\mathrm{C}_{\mathrm{K}}$ are average activity concentrations of ${ }^{226} \mathrm{Ra},{ }^{232} \mathrm{Th}$, and ${ }^{40} \mathrm{~K}$ respectively in the samples.

(d). The indoor contribution is assumed to be 1.2 times higher than the outdoor dose which is $[7,12]$

$$
\mathrm{D}_{\text {indoor }}=\mathrm{D}_{\text {outdoor }} \times 1.2\left(\mathrm{nGy} \cdot \mathrm{h}^{-1}\right)
$$


(e). The formulae for calculating the radium equivalent activity $\mathrm{Ra}_{\mathrm{eq}}$ [11] and the representative level index $\mathrm{I}_{\gamma \mathrm{r}}[7,13-15]$ in the present research used are

$$
\begin{aligned}
& \mathrm{Ra}_{\mathrm{eq}}=\mathrm{C}_{\mathrm{Ra}}+1.43 \mathrm{C}_{\mathrm{Th}}+0.077 \mathrm{C}_{\mathrm{K}} \\
& \mathrm{I}_{\gamma \mathrm{r}}=\left(\mathrm{C}_{\mathrm{Ra}} / 150+\mathrm{C}_{\mathrm{Th}} / 100+\mathrm{C}_{\mathrm{K}} / 1500\right)
\end{aligned}
$$

Where, $\mathrm{C}_{\mathrm{Ra}}, \mathrm{C}_{\mathrm{Th}}$ and $\mathrm{C}_{\mathrm{K}}$ are activity concentrations of ${ }^{226} \mathrm{Ra},{ }^{232} \mathrm{Th}$, and ${ }^{40} \mathrm{~K}$ respectively in the samples respectively.

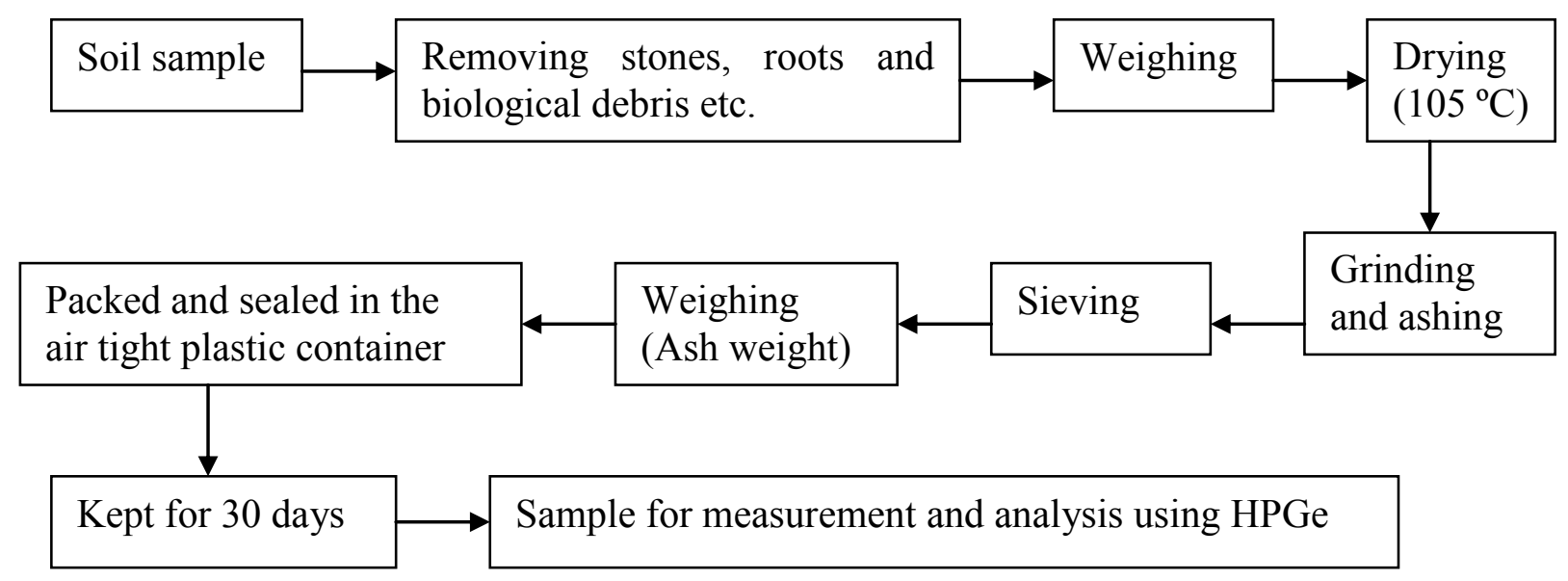

Fig. 2. Flow chart for illustrating the pre-treatment of the soil samples.

\section{RESULTS}

The mean specific activity concentrations of radionuclide's ${ }^{232} \mathrm{Th},{ }^{226} \mathrm{Ra}$, and ${ }^{40} \mathrm{~K}$ have been respectively found to be $52.87 \pm 0.73,23.08 \pm 2.76,426.88 \pm 2.59 \mathrm{~Bq} \cdot \mathrm{kg}^{-1}$ surround the Magurchhera gas field and $57.48 \pm 0.33,22.38 \pm 2.59,369.54 \pm 2.75 \mathrm{~Bq} \cdot \mathrm{kg}^{-1}$ surround the Haripur gas field explosion areas.

The activity concentrations of these radionuclide's have been respectively found to be ranged from $31.51 \pm 0.66$ to $88.99 \pm 0.39,12.00 \pm 2.28$ to $49.6 \pm 2.96$ and $260.04 \pm 1.29$ to $1094 \pm 2.047 \mathrm{~Bq} \cdot \mathrm{kg}^{-1}$ for Magurchhera and $42.09 \pm 0.35$ to $75.12 \pm 0.43,15.25 \pm 2.50$ to $34.45 \pm 2.66$ and $213.47 \pm 1.39$ to $480.37 \pm 2.34 \mathrm{~Bq} \cdot \mathrm{kg}^{-1}$ for Haripur gas field. The artificial radionuclide ${ }^{137} \mathrm{Cs}$ has been detected in most of the sample with an average of $1.65 \pm 0.61$ $\mathrm{Bq} \cdot \mathrm{kg}^{-1}$ around the Magurchhera and $1.13 \pm 0.57 \mathrm{~Bq} \cdot \mathrm{kg}^{-1}$ around the Haripur gas field.

The comparative data of these radionuclides is given Table 1 and the graphical representation for Magurchhara and Haripur gas field are shown in Fig. 3A and 3B respectively. The activity concentrations of radionuclide's ${ }^{232} \mathrm{Th}$ and ${ }^{40} \mathrm{~K}$ have been found to be higher and ${ }^{226} \mathrm{Ra}$ has been found to be lower than that of the world average [12] as well as worldwide value [4]. Again, the comparison of the activity concentration of radionuclide's ${ }^{232} \mathrm{Th},{ }^{226} \mathrm{Ra}$ and ${ }^{40} \mathrm{~K}$ of present study with regional, other countries of the world and worldwide values [4] is given in Table 2.

The graphical comparison of the mean specific activity concentration of the radionuclide's of present results with the results of several countries of the world and 
worldwide value are shown in Fig. 4. The mean value of radiation impact attributes namely radium equivalent activity, representative gamma level index, outdoor dose rate, indoor dose rate have been found to be $131.45 \pm 4.05 \mathrm{~Bq} \cdot \mathrm{kg}^{-1}, 2.30 \pm 0.03 \mathrm{~Bq} \cdot \mathrm{kg}^{-1}, 63.30 \pm 1.82$ $\mathrm{nGy} \cdot \mathrm{h}^{-1}, 75.95 \pm 2.18 \mathrm{nGy} \cdot \mathrm{h}^{-1}$ respectively for Magurchhara and $132.92 \pm 3.28 \mathrm{~Bq} \cdot \mathrm{kg}^{-1}, 0.97$ $\pm 0.02 \mathrm{~Bq} \cdot \mathrm{kg}^{-1}, 63.57 \pm 1.44 \mathrm{nGy} \cdot \mathrm{h}^{-1}, 76.28 \pm 1.73 \mathrm{nGy} \cdot \mathrm{h}^{-1}$ for Haripur gas field respectively.

All these values of these parameters are higher than those of the world average values [12] and their graphical representation are shown in Figs. 5a, 5b and 5c.

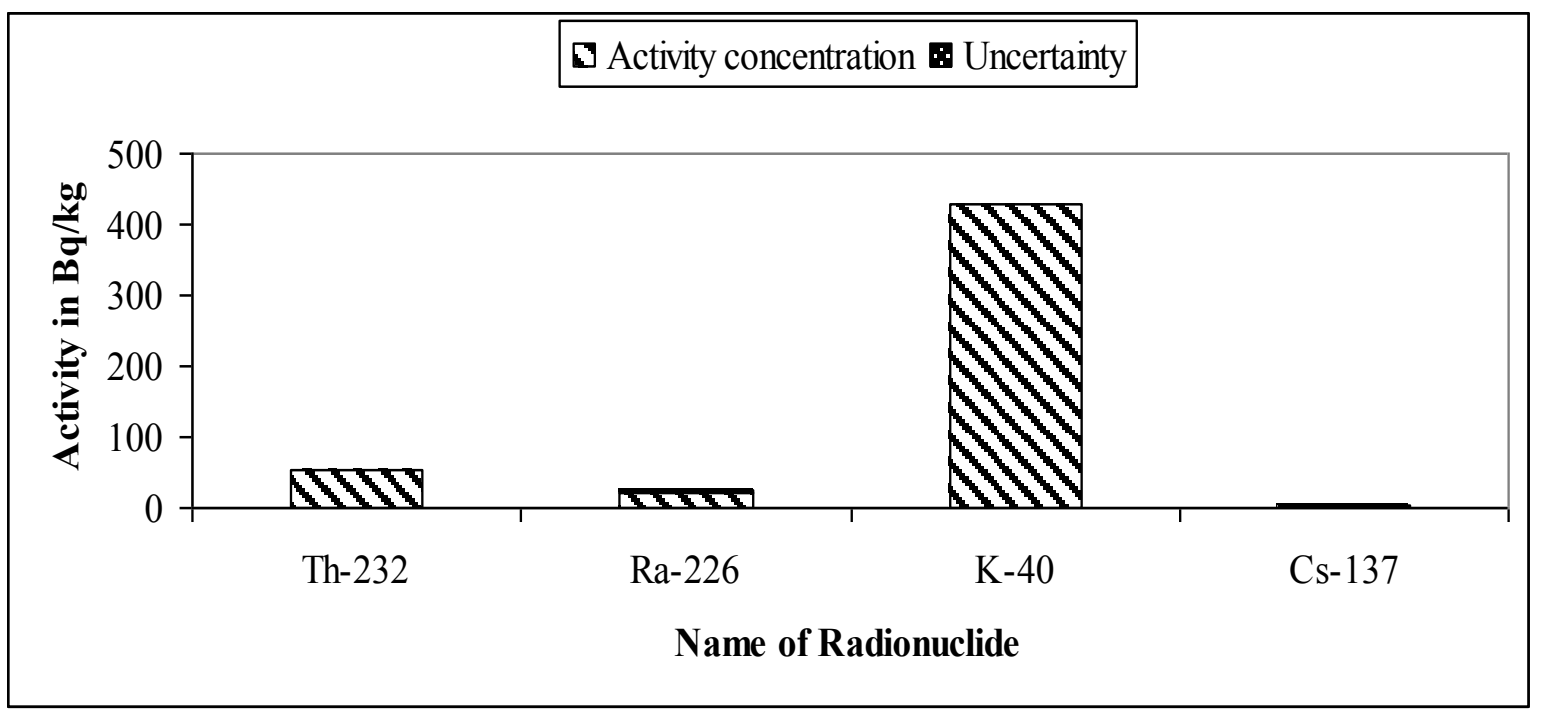

Fig. 3A. Comparison of the activity concentration of radionuclide's in Magurchhera gas field area.

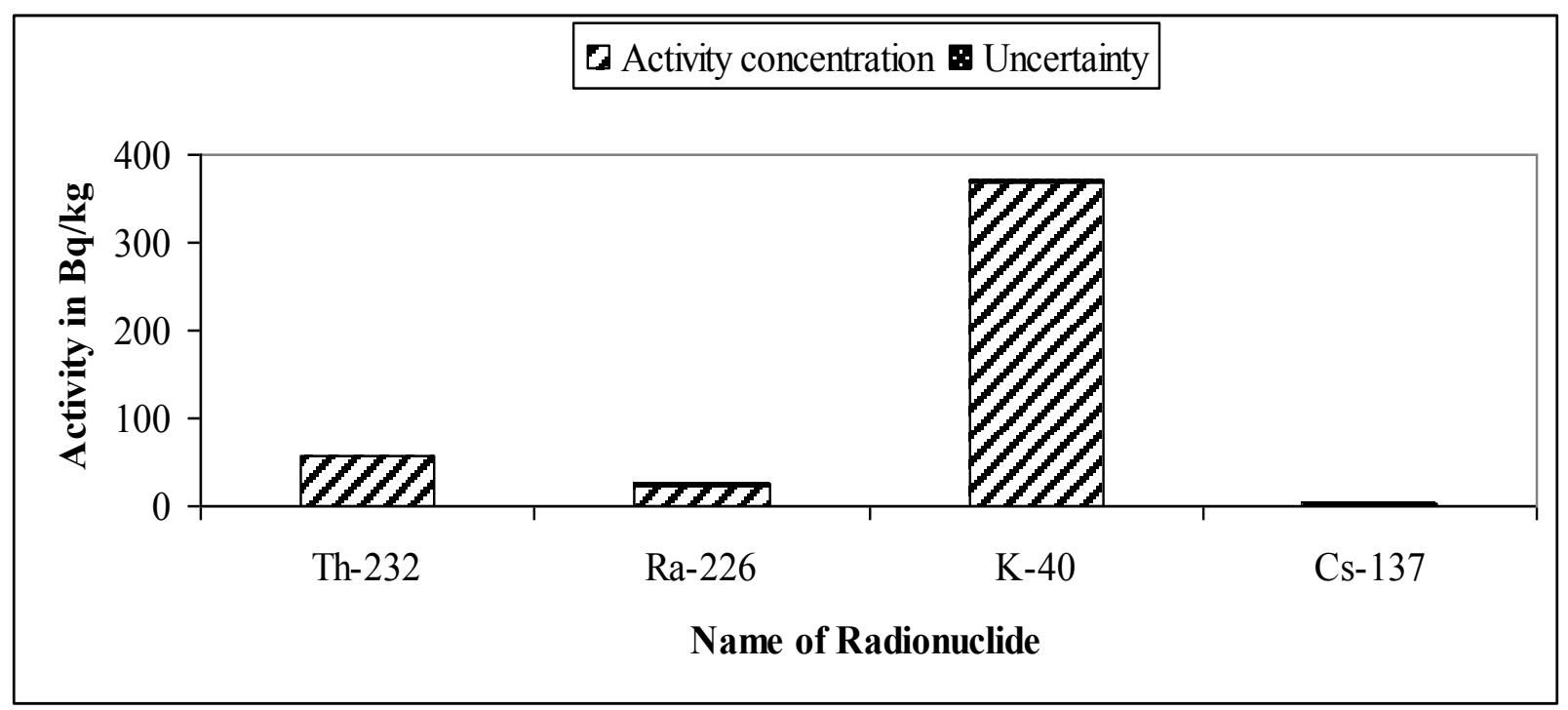

Fig. 3B. Comparison of the activity concentration of radionuclide's in Haripur gas field area. 


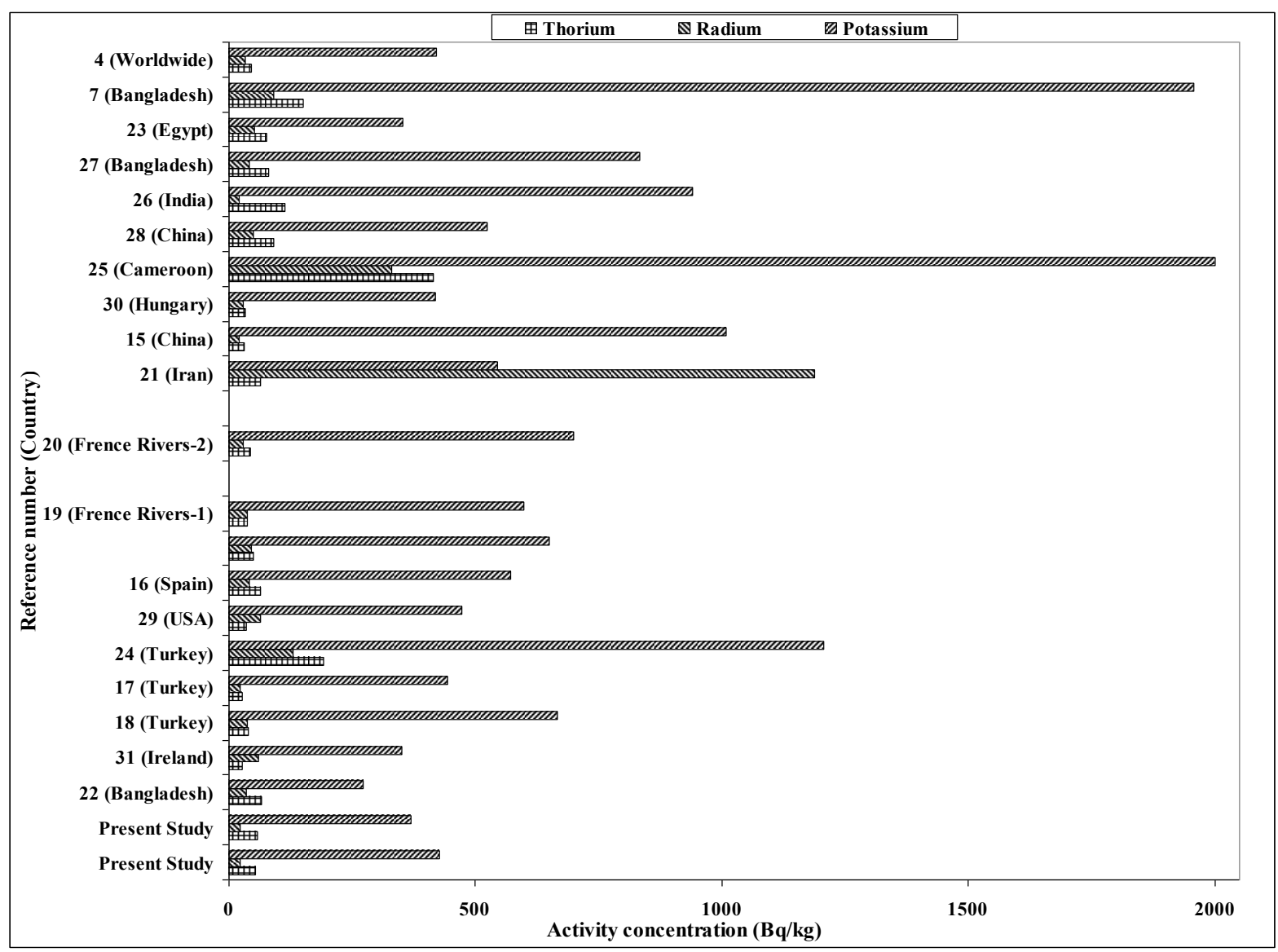

Fig. 4. Comparison of the present results with the results of various countries of the world.

Table 1. Comparative data of the mean activity concentration (in Bq $\cdot \mathrm{kg}^{-1}$ ) of ${ }^{232} \mathrm{Th},{ }^{226} \mathrm{Ra},{ }^{40} \mathrm{~K}$ and ${ }^{137}$ Cs of two study areas.

\begin{tabular}{|c|c|c|c|c|}
\hline \multirow{2}{*}{ Radionuclie } & \multicolumn{2}{|c|}{ Magurchhera gas field } & \multicolumn{2}{|c|}{ Haripur gas field } \\
\hline & Range & Mean & Range & Mean \\
\hline${ }^{232} \mathrm{Th}$ & $\begin{array}{c}31.51 \pm 0.66 \text { to } \\
88.99 \pm 0.39\end{array}$ & $52.87 \pm 0.73$ & $\begin{array}{c}42.09 \pm 0.35 \text { to } \\
75.12 \pm 0.43\end{array}$ & $57.48 \pm 0.33$ \\
\hline${ }^{226} \mathrm{Ra}$ & $\begin{array}{c}12.00 \pm 2.28 \text { to } \\
49.6 \pm 2.96\end{array}$ & $23.08 \pm 2.76$ & $\begin{array}{c}15.25 \pm 2.50 \text { to } \\
34.45 \pm 2.66\end{array}$ & $22.38 \pm 2.59$ \\
\hline${ }^{40} \mathrm{~K}$ & $\begin{array}{c}260.04 \pm 1.219 \text { to } \\
1094.21 \pm 2.04\end{array}$ & $426.88 \pm 2.59$ & $\begin{array}{c}213.47 \pm 1.39 \text { to } \\
480.37 \pm 2.34\end{array}$ & $369.54 \pm 2.75$ \\
\hline${ }^{137} \mathrm{Cs}$ & $\begin{array}{l}\text { N. D. }{ }^{*} \text { to } \\
3.06 \pm 0.45\end{array}$ & $1.65 \pm 0.61$ & $\begin{array}{c}\text { N. D. to } \\
2.61 \pm 0.51 \\
\end{array}$ & $1.13 \pm 0.57$ \\
\hline
\end{tabular}

N. D. $=$ Not Detected 
Table 2. Comparison of the mean activity concentration of ${ }^{232} \mathrm{Th},{ }^{226} \mathrm{Ra}$ and ${ }^{40} \mathrm{~K}$ (in Bq$\cdot \mathrm{kg}^{-1}$ ) of present results with regional, other study areas of the world and worldwide values.

\begin{tabular}{|c|c|c|c|c|c|}
\hline $\begin{array}{r}\text { Sl } \\
\text { No. }\end{array}$ & $\begin{array}{c}\text { Referen } \\
\text { ces }\end{array}$ & Area & ${ }^{232} \mathrm{Th}$ & ${ }^{226} \mathbf{R a}$ & ${ }^{40} \mathrm{~K}$ \\
\hline \multirow[t]{2}{*}{1} & Present & Magurchhara gas field & $52.87 \pm 0.73$ & $23.08 \pm 2.76$ & $426.88 \pm 2.59$ \\
\hline & & Haripur gas field & $57.48 \pm 0.33$ & $22.38 \pm 2.59$ & $369.54 \pm 2.75$ \\
\hline 2 & 22 & $\begin{array}{l}\text { River Sediments and } \\
\text { Coastal Soils of }\end{array}$ & $65.5 \pm 12.2$ & $35.9 \pm 18.9$ & $272 \pm 35$ \\
\hline 3 & 31 & Republic of Ireland & 26 & 60 & 350 \\
\hline 4 & 18 & Kirklareli & $40 \pm 18$ & $37 \pm 17$ & $667 \pm 282$ \\
\hline 5 & 17 & South of Marmara, Turkey & $26.6 \pm 16$ & $22.5 \pm 13$ & $443 \pm 190$ \\
\hline 6 & 24 & Kestanbol & 192 & 130.93 & 1207 \\
\hline 7 & 29 & Lousiana, USA & $36 \pm 12$ & $64 \pm 17$ & $472 \pm 223$ \\
\hline \multirow[t]{2}{*}{8} & 16 & River Tagus & 63 & 42 & 572 \\
\hline & & All soils & 49 & 45 & 650 \\
\hline 9 & 19 & French Rivers-1 & 38 & 38 & 599 \\
\hline 10 & 20 & French Rivers- 2 & 44 & 28 & 700 \\
\hline 11 & 21 & Western Mazandaran & 64.92 & 1188.5 & 545.10 \\
\hline 12 & 15 & $\begin{array}{l}\text { Province, Iran. } \\
\text { Geological Park, China. }\end{array}$ & $\begin{array}{l} \pm 162.26 \\
30.1\end{array}$ & $\begin{array}{l} \pm 7838.4 \\
20.4\end{array}$ & $\begin{array}{l} \pm 139.42 \\
1009.5\end{array}$ \\
\hline 13 & 30 & Hungary & 32.1 & 29.7 & 418 \\
\hline 14 & 25 & South Cameroon & $414 \pm 309$ & $329 \pm 491$ & $2001 \pm 521$ \\
\hline 15 & 28 & China & $89.8 \pm 74$ & $49.7 \pm 35$ & $524 \pm 162$ \\
\hline 16 & 26 & $\begin{array}{l}\text { Kanyakumari District } \\
\text { (India). }\end{array}$ & $114 \pm 97$ & $20 \pm 14$ & $940 \pm 742$ \\
\hline 17 & 27 & $\begin{array}{l}\text { Southern Districts of } \\
\text { Bangladesh }\end{array}$ & $81 \pm 14$ & $42 \pm 7$ & $833 \pm 358$ \\
\hline 18 & 23 & $\begin{array}{l}\text { Nile River Sediments In } \\
\text { Upper Egypt }\end{array}$ & $76.2 \pm 6.2$ & $52 \pm 7.3$ & $351.9 \pm 17.6$ \\
\hline 19 & 17 & $\begin{array}{l}\text { Northern Districts of } \\
\text { Bangladesh }\end{array}$ & $151 \pm 24$ & $91 \pm 10$ & $1958 \pm 400$ \\
\hline 20 & 4 & Worldwide & $45(11-64)$ & $33(17-60)$ & $420(140-850)$ \\
\hline
\end{tabular}




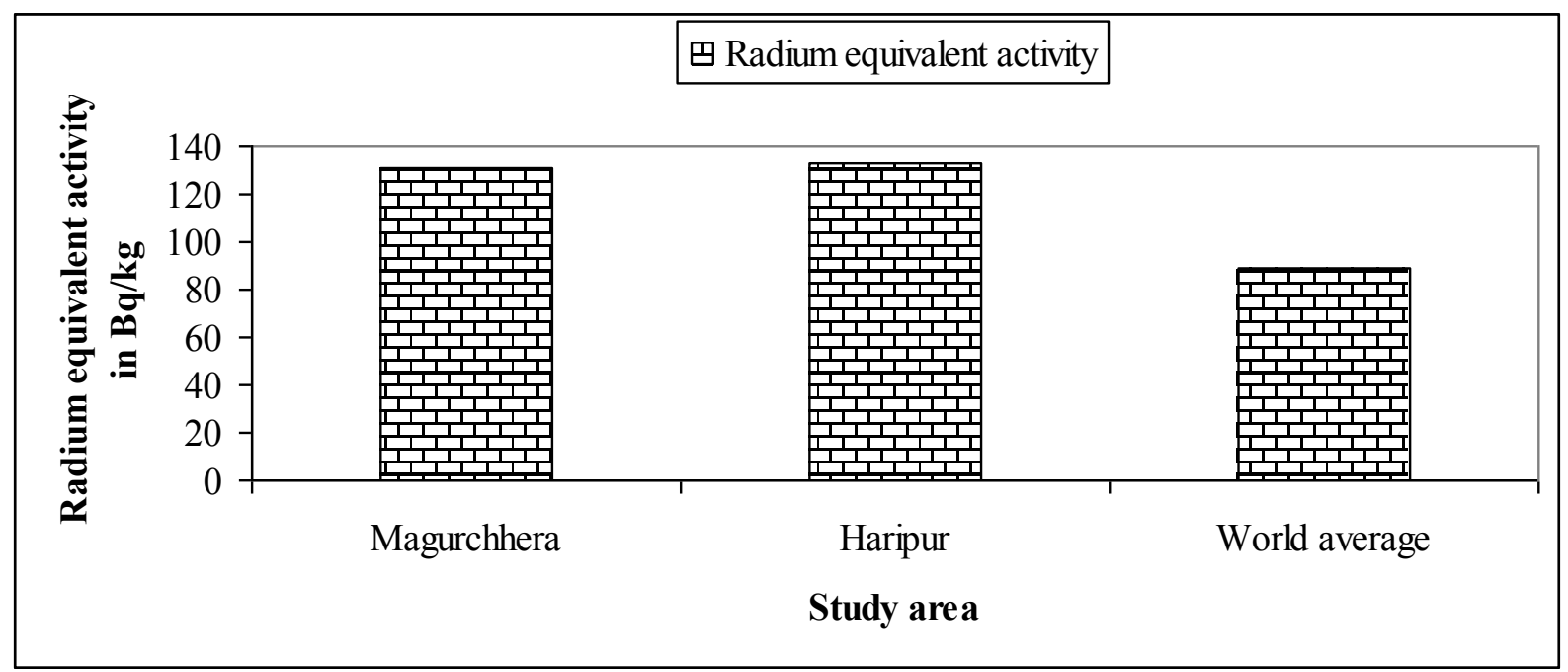

Fig. 5a. Comparison of the mean radium equivalent activity with world average value.

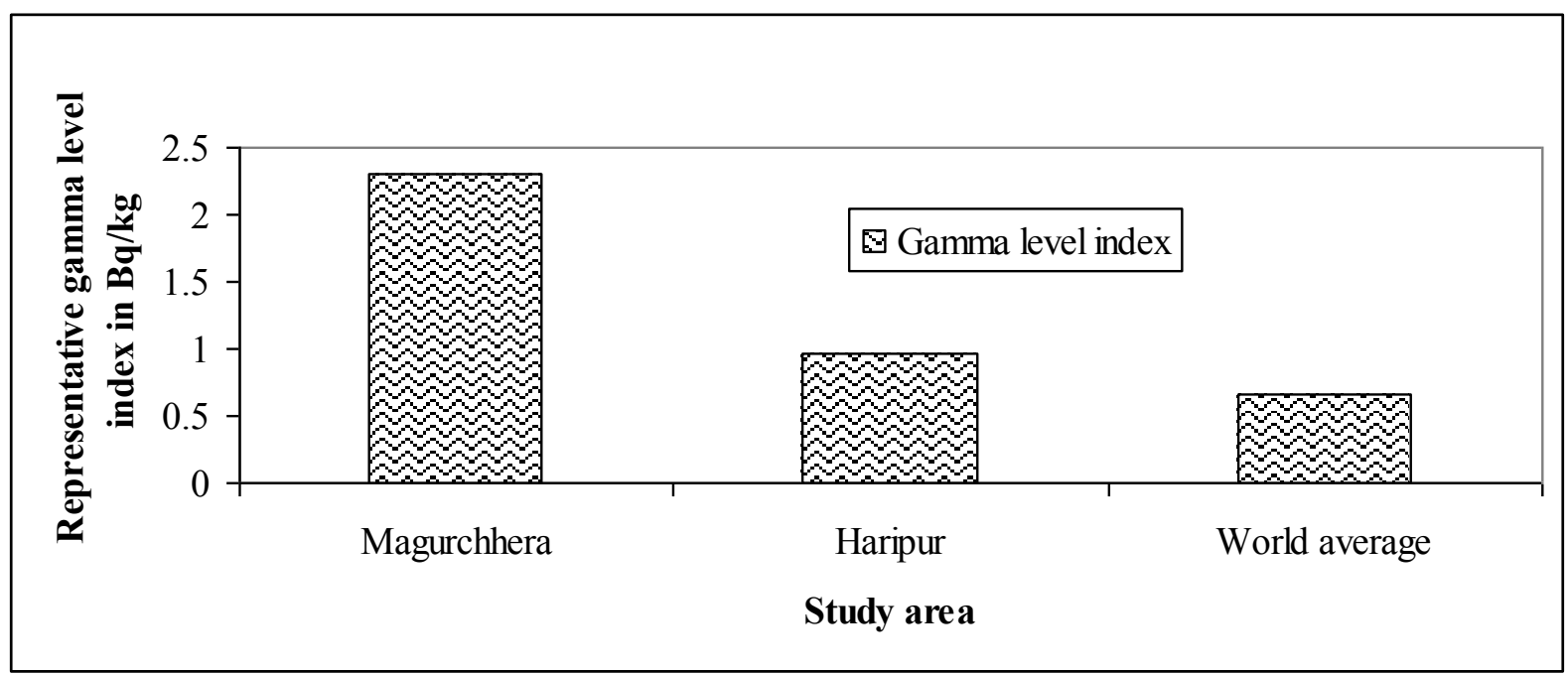

Fig. 5b. Comparison of the mean gamma level index with world average value.

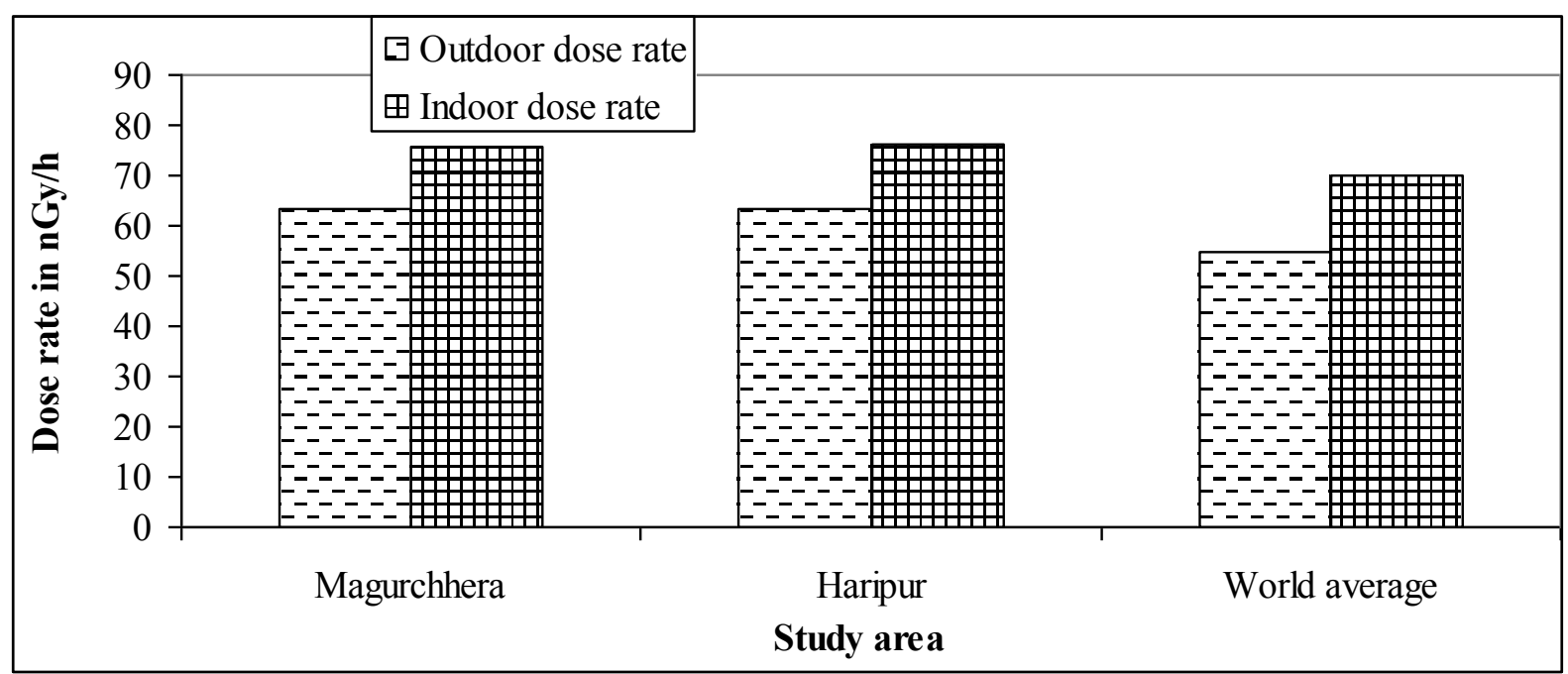

Fig. 5c. Comparison of the mean outdoor and indoor dose rate with world average value. 


\section{DISCUSSION}

It has been found that the concentrations of Th and U-series' radionuclide's $\left({ }^{232} \mathrm{Th}\right.$, ${ }^{226} \mathrm{Ra}$ ) and ${ }^{40} \mathrm{~K}$ in the Magurchhera and Haripur gas field areas are relatively moderate in concentration than those of the other reported areas of the world. The mean activity concentration of ${ }^{232} \mathrm{Th}$ in the these gas well areas has been found to be higher than those of the Turkey [17], Kirklareli [18], Ireland [31], Louisiana-USA [29], French rivers-1 [19], French rivers-2 [20], China [15] and Hungary [30],. It is about to 1.6 times and 2.11 times higher for Magurchhara and 1.74 times and 2.29 times higher for Haripur area than the worldwide value [4] (Table 3) and world average [12] (Table 3) respectively. However, the mean activity concentration of ${ }^{232} \mathrm{Th}$ has been found to be lower than those of the Kestanbol [24], Iran [21], regional study [22], Egypt [23], South Cameroon [25], India [26], Southern Districts of Bangladesh [27], China [28] and Northern Districts of Bangladesh 7 (Table 2).

The mean specific radioactivity level of ${ }^{226} \mathrm{Ra}$ in the study areas has been found to be higher than those of the Turkey [17], India [26], China [15], although it has been found to be lower than those of the Kestanbol [24], Kirklareli [18], Spain [16], French rivers-1 [19], French rivers-2 [20], Ireland [31], Iran [21], regional study [22], Egypt [23], Southern Districts of Bangladesh [27], South Cameroon [25], Louisiana-USA [29] and Northern Districts of Bangladesh [7] (Table 2). It has been found to be about 0.51 times and 0.92 times for Magurchhera and 0.50 times and 0.89 times for Haripur than the worldwide value [4] (Table 3) and world average [12] (Table 3) values respectively.

Table 3. Comparison of overall results of the present study with corresponding world average values, worldwide value and regional study.

\begin{tabular}{|c|c|c|c|c|c|c|}
\hline Study Area & $\begin{array}{c}\text { Finding } \\
\text { Attributes }\end{array}$ & $\begin{array}{c}\text { Results of } \\
\text { Present Study } \\
\text { (average } \pm 1 \sigma)\end{array}$ & $\begin{array}{l}\text { Regional } \\
\text { Study [22] }\end{array}$ & $\begin{array}{c}\text { World } \\
\text { Average } \\
{[12]}\end{array}$ & $\begin{array}{c}\text { World } \\
\text { Wide [4] }\end{array}$ & $\begin{array}{l}\text { Ratio: present } \\
\text { average/ } \\
\text { world average } \\
\text { (Wide) }\end{array}$ \\
\hline \multirow{7}{*}{ 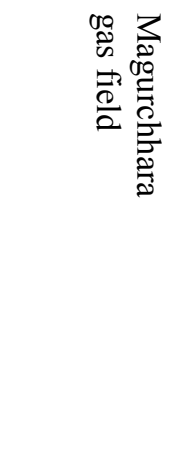 } & ${ }^{232} \mathrm{Th}\left(\mathrm{Bq} \cdot \mathrm{kg}^{-1}\right)$ & $52.87 \pm 0.73$ & $35.9 \pm 18.9$ & 25 & 33 & $2.11(1.6)$ \\
\hline & ${ }^{226} \mathrm{Ra}\left(\mathrm{Bq} \cdot \mathrm{kg}^{-1}\right)$ & $23.08 \pm 2.76$ & $65.5 \pm 12.2$ & 25 & 45 & $0.92(0.51)$ \\
\hline & ${ }^{40} \mathrm{~K}\left(\mathrm{~Bq} \cdot \mathrm{kg}^{-1}\right)$ & $426.88 \pm 2.59$ & $272 \pm 35$ & 370 & 420 & $1.15(1.02)$ \\
\hline & $\mathrm{I}_{\gamma \mathrm{r}}\left(\mathrm{Bq} \cdot \mathrm{kg}^{-1}\right)$ & $2.30 \pm 0.03$ & $1.08 \pm 0.27$ & 0.66 & - & 3.48 \\
\hline & $\mathrm{Ra}_{\mathrm{eq}}\left(\mathrm{Bq} \cdot \mathrm{kg}^{-1}\right)$ & $131.45 \pm 4.05$ & $151 \pm 39$ & 89 & - & 1.48 \\
\hline & $\begin{array}{l}\text { Outdoor Dose } \\
\left(\mathrm{nGy} \cdot \mathrm{h}^{-1}\right)\end{array}$ & $63.30 \pm 1.82$ & $70.78 \pm 18.26$ & 55 & - & 1.15 \\
\hline & $\begin{array}{l}\text { Indoor Dose } \\
\left(\mathrm{nGy} \cdot \mathrm{h}^{-1}\right)\end{array}$ & $75.95 \pm 2.18$ & - & 70 & - & 1.09 \\
\hline \multirow{7}{*}{ 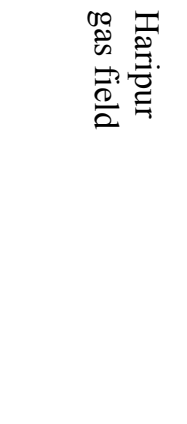 } & ${ }^{232} \mathrm{Th}\left(\mathrm{Bq} \cdot \mathrm{kg}^{-1}\right)$ & $57.48 \pm 0.33$ & $35.9 \pm 18.9$ & 25 & 33 & $2.29(1.74)$ \\
\hline & ${ }^{226} \mathrm{Ra}\left(\mathrm{Bq} \cdot \mathrm{kg}^{-1}\right)$ & $22.38 \pm 2.59$ & $65.5 \pm 12.2$ & 25 & 45 & $0.89(0.50)$ \\
\hline & ${ }^{40} \mathrm{~K}\left(\mathrm{~Bq} \cdot \mathrm{kg}^{-1}\right)$ & $369.54 \pm 2.75$ & $272 \pm 35$ & 370 & 420 & $1.0(0.88)$ \\
\hline & $\mathrm{I}_{\gamma \mathrm{r}}\left(\mathrm{Bq} \cdot \mathrm{kg}^{-1}\right)$ & $0.94 \pm 0.02$ & $1.08 \pm 0.27$ & 0.66 & - & 1.42 \\
\hline & $\mathrm{Ra}_{\mathrm{eq}}\left(\mathrm{Bq} \cdot \mathrm{kg}^{-1}\right)$ & $132.92 \pm 3.28$ & $151 \pm 39$ & 89 & - & 1.49 \\
\hline & $\begin{array}{l}\text { Outdoor Dose } \\
\left(n G y \cdot h^{-1}\right)\end{array}$ & $63.57 \pm 1.44$ & $70.78 \pm 18.26$ & 55 & - & 1.16 \\
\hline & $\begin{array}{l}\text { Indoor Dose } \\
\left(\mathrm{nGy} \cdot \mathrm{h}^{-1}\right)\end{array}$ & $76.28 \pm 1.73$ & - & 70 & - & 1.09 \\
\hline
\end{tabular}


The mean specific radioactivity level of ${ }^{40} \mathrm{~K}$ in the soil samples has been found to be higher than those of the regional study [22], Ireland [31], Hungary [30], Egypt [23], but the activity concentration of ${ }^{40} \mathrm{~K}$ has been found to be lower than those of the Turkey [17], Kirklareli [18], Spain [16], French rivers-1 [19], French rivers-2 [20], Iran [21], Southern Districts of Bangladesh [27], Kestanbol [24], China [15], South Cameroon [25], Northern Districts of Bangladesh [7], and India [26] (Table 2). The specific activity of ${ }^{40} \mathrm{~K}$ has been found to be about 1.02 times and 1.15 times higher for Magurchhera area than the worldwide value [4] (Table 3) and world average [12] (Table 3) value respectively; similar results have also been found for Haripur area. Although, the artificially produced anthropogenic radionuclide ${ }^{137} \mathrm{Cs}$ has been detected in most of the samples in low level, further study is necessary for confirming that's the anthropogenic radionuclide remained in these gas well areas. The mean values of the representative level index $\mathrm{I}_{\gamma \mathrm{r}}$, radium equivalent activity $\mathrm{Ra}_{\mathrm{eq}}$, outdoor dose rate and indoor dose rate due to the radioactivity in the Magurchhera and Haripur gas well areas have been found to be higher than those of the world average [12] (Table 3) values.

\section{CONCLUSION}

The average activity of ${ }^{226} \mathrm{Ra}$ in the study areas is comparable with the average value, but it is higher than the world average value in case of ${ }^{232} \mathrm{Th}$. In Magurchhera area, the mean activity of ${ }^{40} \mathrm{~K}$ is higher than the world average value [12], but for Haripur area it coincides with the world average value. The mean activity of ${ }^{137} \mathrm{Cs}$ has been found very little in the study areas. So it may be concluded that the Magurchhera gas field as well as Haripur gas field area has not been contaminated by ${ }^{137} \mathrm{Cs}$ due to the accident occurred there. The values of the dose rates, radium equivalent activity and gamma level index recommend that the environment of the study areas is safe for the public health in respect of radioactivity.

\section{References}

[1] Ahmad Saat, Nurulhuda Kassim, Zaini Hamzah, Ahmad Farisz, Journal of Nuclear and Related Technologies 7(2) (2010) 49-54.

[2] Blackburn R., Radiation Physics and Chemistry 26(1) (1985) 117.

[3] Teodere D. F., Edwards J. N., Soc. Sci. Med. 36 (11) (1993) 1417-1428.

[4] UNSCEAR (United Nations Scientific Committee on the Effects of Atomic Radiation), Sources and Biological Effects of Ionizing Radiation, Annex B: Exposures from Natural Radiation Sources. New York, (2000). Available at

[5] Fukushima Hiroto (Dr.), "Sample Treatment and Sample Preparation", Text Book on Determination of Radionuclide's in Food and Environmental Samples. Principal Researcher, IAEA, Regional Training Course Tokyo and Tokai, Japan, International Atomic Energy Agency (IAEA), Japan Atomic Energy Research Institute (JAERI), 2-31 March, 1992, L 15, P-27.

[6] Reference and intercomparison materials for stable isotopes of light elements. IAEA, Vienna-1995, IAEA-TECDOC-825, ISSN 1011-4289.

Available at http://www-pub.iaea.org/MTCD/publications/PDF/te_825_prn.pdf 
[7] Hamid B. N., Chowdhury M. I., Alam M. N., Islam M. N., Rad Prot Dosim 98(2) (2002) 227-230.

[8] Cutshall N. H., Larsen I. L., Olesen C. R., Nucl Instrum Methods Phys Res 206 (1-2) (1983) 309-312.

[9] Kitto M. E., Applied Radiation and Isotopes 42(9) (1991) 835-839.

[10] El-Taher A., Rad Prot Dosim 138(2) (2010) 166-173.

[11] Jabbar T., Khan K., Subhani M. S., Akhter P., Jabbar A., Rad Prot Dosim 132(1) (2008) $88-93$.

[12] UNSCEAR (United Nations Scientific Committee on the Effects of Atomic Radiation), Exposure from Natural Sources of Radiation, Report to the General Assembly, with annexes; United Nations, New York, (1988). Available at http://www.unscear.org/docs/reports/1988/1988b_unscear.pdf, http://www.unscear.org/docs/reports/1988/1988c_unscear.pdf, http://www.unscear.org/docs/reports/1988/1988a_unscear.pdf

[13] Beretka J., Mathew P. J., Health Phys. 48 (1985) 87-95.

[14] NEA/OECD Nuclear Energy Agency (NEA\#06711). Exposure to Radiation from Natural Radioactivity in Building Materials. Report by NEA Group of Experts (Paris: OECD), (1979). Available at http://www.oecd-nea.org/rp/reports/1979/exposure-to-radiation-1979.pdf

[15] Xinwei Lu, Xiaolan Zhang, Rad Prot Dosim 128(1) 92008) 77-82.

[16] Baeza A., Del Rio, Miro C., Paniagua J. M., Rad Prot Dosim 45 (1/4) (1992) 261-263

[17] Onder Kilic, Murat Belivermis, Sayhan Topcuoglu, Yavuz Cotuk, Mahmut Coskun, Akin Kayir, Rahmi Kucer, Rad Prot Dosim 128(3) (2008) 324-330.

[18] Taskin H., Karavus M., Ay P., Topuzoglu A., Hidiroglu S., Karahan G., J. Environ Radioact 100(1) (2009) 49-53.

[19] Lambrechts A., Foulquier L., Garnier-Laplace J., Rad Prot Dosim 45(1-4) (1992) 253-256.

[20] Descamps B., Foulquier L., Rad Prot Dosim 24(1-4) (1988) 143-147.

[21] Abbaspour M., Moattar F., Okhovatian A., Kharrat M., Rad Prot Dosim 142(2-4) (2010) 265-272.

[22] Chowdhury M. I., Alam M. N., Hazari S. K. S., Appl Radiat Isot 51(6) (1999) 747-755.

[23] Uosif M. A. M., Rad Prot Dosim 123(2) (2007) 215-220.

[24] Merdanoglu B., Altinsoy N., Rad Prot Dosim 121(4) (2006) 399-405.

[25] Beyala Ateba J. F., Owono Ateba P., Ben-Bolie G. H., Ele Abiama P., Abega C. R., Mvondo S., Rad Prot Dosim 140(1) (2010) 81-88.

[26] Shanthi G., Thampi Thanka Kumaran J., Allen Gnana Raj G., Maniyan C. G., Rad Prot Dosim 141(1) (2010) 90-96.

[27] Chowdhury M. I., Kamal M., Alam M. N., Saleha Yeasmin, Mostafa M. N., Rad Prot Dosim 118(1) (2006) 126-130. 
[28] Ziqiang P., Yin Y., Mingqiang G., Rad Prot Dosim 24(1-4) (1988) 29-38.

[29] Delune R. D., Jones G. L., Smith C. J., Health Phys. 51(2) (1986) 239-244.

[30] Papp Z., Rad Prot Dosim 141(1) (2010) 56-63.

[31] McAulay I. R., Moran D., Rad Prot Dosim 24(1-4) (1988) 47-49. 